\title{
Evaluation of A Four Stroke Compression-Ignition Engine with Load (100N).
}

\author{
S. Idogwu ${ }^{1^{*}} \quad$ Dr. T. O. Onah ${ }^{1} \quad$ B. Ugwuanyi ${ }^{2}$ \\ 1.Department of Mechanical and Production Engineering, Enugu State University of Science and Technology \\ Enugu, Nigeria \\ 2. Department of Biomedical Engineering, Federal School of Dental and Therapy, Enugu, Nigeria
}

\begin{abstract}
DOI: $10.7176 /$ JETP/9-8-04

Publication date: November $30^{\text {th }} 2019$

Nomenclature :

$\mathrm{L}=\operatorname{Load}(\mathrm{N})$

$\mathrm{T}=$ Torque $(\mathrm{N}-\mathrm{m})$

$\mathrm{N}=$ Shaft speed (rpm)

$\mathrm{BP}=$ Brake Power $(\mathrm{Kw})$

$\mathrm{Q}=$ Volume flow rate $\left(\mathrm{m}^{3} / \mathrm{s}\right)$

$\mathrm{BHP}=$ Brake Horse Power $(\mathrm{Kw})$

$\mathrm{IP}=$ Indicated Power $(\mathrm{Kw})$

$\mathrm{mf}=$ mass flow rate of fuel $(\mathrm{kg} / \mathrm{h})$

$\eta_{\mathrm{m}}=$ Mechanical efficiency $(\%)$

$\mathrm{SFC}=$ Specific Fuel Consumption $(\mathrm{kg} / \mathrm{kwh})$
\end{abstract}

A loaded four stroke compression ignition (Nissan Primera model) engine mounted in a heat engine laboratory of Enugu State University of Science and Technology Enugu was used for the exercise. An absorption dynamometer was attached to the engine to measure torque. As the engine was running, the speed was recorded with a digital tachometer at a time frame of 20 seconds. A lot of tests were carried out to determine a number of parameters like specific fuel consumption, mechanical efficiency, fuel mass flow rate, indicated power, brake power, brake horse power, rate of fuel consumption at different gear ratios. The data so obtained were tabulated and relationship between various parameters plotted in graphs. Results show that: volume of diesel consumed increases with increasing engine speed, increases with increasing gear; mass flow rate of diesel increases with increasing brake power, increases with increasing gear; specific fuel consumption decreases with increasing engine speed ; specific fuel consumption also decreases with increasing brake power; indicated power increases as engine speed increases. Keywords: Diesel Engine, Absorption Dynamometer, Tachometer, Engine Torque, Brake Horse Power,

\section{0: INTRODUCTION:}

The compression-ignition engine is an internal combustion engine designed to convert the chemical energy available in fuel into mechanical energy. This mechanical energy moves pistons up and down inside cylinders (Baumgarter and Carsten, 2006).

The two basic mechanical designs of this engine are 2 - stroke and 4 - stroke, which are used to achieve the operational sequence of intake, compression, combustion and exhaust strokes (Heywood,1998). In a four stroke combustion cycle of compression-ignition engine, air is drawn into the cylinder on the first stroke, compressed on the second stroke, fuel is injected and ignited on the third stroke and the products of combustion are exhausted on the fourth stroke (Khurmi and Gupta,2000).

Compression-ignition engine usually has longer stroke length chiefly to facilitate achieving the necessary compression ratios, but also to reduce the optimal operating speed (Eastop and McConkey,2006). The engine has the highest thermal efficiency of any standard internal or external combustion engine due to its very high compression ratio and inherent lean burn which enables heat dissipation by the excess air (Ganeshan, 2008).

The internal combustion engine is used to power nearly all land vehicles and many water- based and air based vehicles as well (Khurmi and Gupta,2000).

\section{1: BASIC PARAMETERS USED TO EXPRESS THE PERFORMANCE OF A FOUR STROKE DIESEL ENGINE.}

Power: The main purpose of running an engine is to obtain mechanical power. Power is defined as the rate of doing work and is equal to the product of force and linear velocity or the product of torque and angular velocity.

Brake Power (BP): The power developed by an engine and measured at the output shaft is called the brake power and is expressed by Eastop and McConkey (2005) as: 


$$
B P=\frac{2 \Pi N r W}{60}
$$

Indicated Power (IP) :It is defined as the power developed by combustion of fuel in the cylinder of engine Eastop and McConkey (2005) as:

$I P=\frac{P L A N W}{60}$

Mechanical efficiency $\left(\eta_{\mathrm{m}}\right)$ : This is defined as the ratio of brake power to indicated power and is expressed by Eastop and McConkey (2005) as:

$$
\eta_{m}=\frac{B P}{I P}
$$

Specific fuel consumption (SFC): It is the quantity of fuel consumed to produce one unit of power in one unit of time and is expressed by Nag (2001), Rai (2006) as:

$$
S F C=\frac{m f}{B P}
$$

Volume flow rate (Q): This is the amount of fuel consumed in specific time and is expressed by Rai (2006), Onkar (2008) as:

$$
Q=\frac{v}{t}
$$

Fuel Mass Flow Rate (mf): Fuel mass flow rate in $\mathrm{kg} / \mathrm{h}$ is expressed by Eastop and McConkey (2005) as:

$m f=Q x s . g . x d e n s i t y o f w a t e r(1000) x 3600$

Where: $\mathrm{Q}$ is volume flow rate

s.g. is specific gravity of diesel $=0.81$

\section{0: MATERIALS USED:}

Laser Tachometer: This is a digital device used to measure the speed and rotation of an engine shaft.

Absorption Dynamometer: The absorption dynamometer used in the laboratory was positioned at a known distance $0.30 \mathrm{~m}$ to the gear box. Based on the force recorded in the load cell and known distance, a torque can be calculated. This torque is recorded along with the angular velocity of the crankshaft (engine speed) and together they define power.

Engine: The engine tested in the laboratory is a four stroke diesel engine (Nissan primera model). The specifications and published performance data are listed below.

Engine type...........................turbocharged diesel

Cylinder area............................0.001785m2

Bore.....................................0.0885m

Stroke...................................0.088m

Compression ratio...........................22.3:1

Shaft radius.............................. $0.005 \mathrm{~m}$

Number of cylinder............................4

Gas flow meter: This measures the volumetric flow rate of a fluid.

Burette and stopwatch: These are used to measure the gas flow rate into the engine.

\section{1: METHODS OF EXPERIMENTATION}

\section{Fuel consumption tests:}

The quantity of fuel consumed by the engine on a test bed is easily carried out by using fuel measuring device like burette.

The burette filled with diesel was connected to the injector with a hose. The engine was started and the initial level of diesel in the burette was recorded immediately and timing started. The throttle control of the engine was gradually increased while placing the tachometer at the output of engine shaft till it (tachometer) displayed the required speed. Also the final level of diesel was recorded when the stopwatch reached the required time (20 seconds). The volume of diesel consumed was the difference in reading between the initial and final values.

Determination of brake power at varying gear and speed:

The engine was loaded with a load measured with a spring balance. Then it was started at a known gear and speed, and the initial level of diesel in the burette was recorded immediately and timing started. Also the final level of diesel was recorded when the stopwatch reached the required time ( 20 seconds). Mathematically, 
Brake Power $(\mathrm{BP})=\frac{2 \Pi N r W}{60}$

Where: $\mathrm{N}$ is engine speed (rpm)

$\mathrm{r}$ is shaft radius $=0.005 \mathrm{~m}$

$\mathrm{W}$ is $\mathrm{Load}=100 \mathrm{~N}$

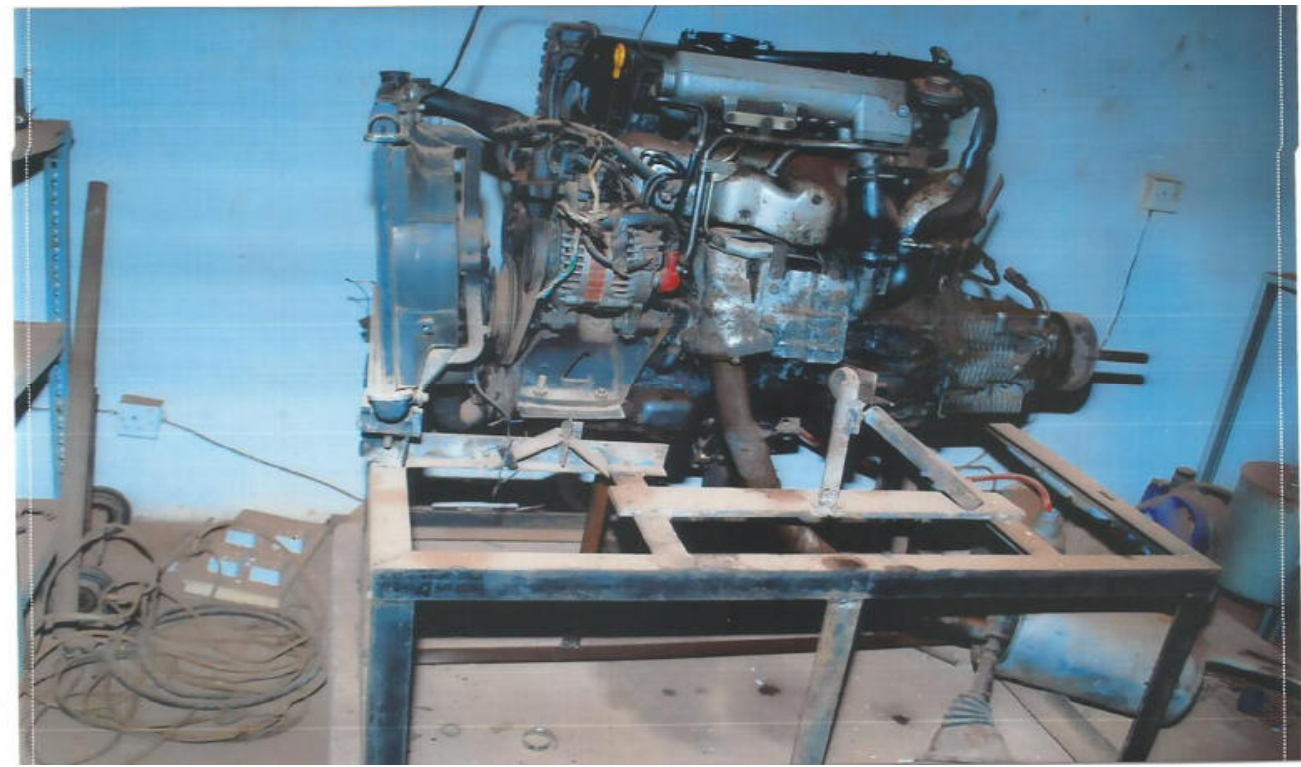

Fig 1. Picture of the test bed set-up

\section{0: RESULTS AND DISCUSSIONS}

Actual speed values obtained ---700, 900, 1100 and $1300 \mathrm{rpm}$

Stroke length,L-----0.088m

Area of cylinder,A..............0.001785 $\mathrm{m}^{2}$

Fuel used -----diesel

Specific gravity of diesel ----- 0.81

Radius of rotating shaft, $\mathrm{r}$-----0.005m (measured with vernier caliper)

Number of cylinder -------4

Mean effective pressure,P --- 101.325kpa

Load, W

$.100 \mathrm{~N}$

\section{1: Results of the various tests are recorded on table 1.}

Table 1. Results of test at load 100N

\begin{tabular}{|c|c|c|c|c|}
\hline Gear & Load, W(N) & $\begin{array}{l}\text { Speed, } \\
\text { N(rpm) }\end{array}$ & $\begin{array}{l}\text { Time, } \mathrm{t} \\
(\mathrm{sec} .)\end{array}$ & Volume of gas consumed, $\mathrm{V}_{\mathrm{f}(\mathrm{ml})}$ \\
\hline \multirow[t]{4}{*}{1} & 100 & 700 & 20 & 8.20 \\
\hline & & 900 & & 8.90 \\
\hline & & 1100 & & 9.45 \\
\hline & & 1300 & & 9.80 \\
\hline \multirow[t]{4}{*}{2} & 100 & 700 & 20 & 11.90 \\
\hline & & 900 & & 12.15 \\
\hline & & 1100 & & 12.60 \\
\hline & & 1300 & & 13.00 \\
\hline \multirow[t]{4}{*}{3} & 100 & 700 & 20 & 14.00 \\
\hline & & 900 & & 15.10 \\
\hline & & 1100 & & 16.25 \\
\hline & & 1300 & & 16.90 \\
\hline \multirow[t]{4}{*}{4} & 100 & 700 & 20 & 17.00 \\
\hline & & 900 & & 19.00 \\
\hline & & 1100 & & 20.10 \\
\hline & & 1300 & & 21.50 \\
\hline
\end{tabular}


Table 2. The results of engine parameters obtained at gear 1

\begin{tabular}{llllllll}
\hline $\mathrm{s} / \mathrm{n}$ & Parameters & symbol & unit & Trial 1 & Trial 2 & Trial 3 & Trial 4 \\
\hline 1 & Time & $\mathrm{t}$ & $\mathrm{Sec}$ & 20 & 20 & 20 & 20 \\
2 & Speed & $\mathrm{N}$ & $\mathrm{rpm}$ & 700 & 900 & 1100 & 1300 \\
3 & Volume of gas consumed & $\mathrm{Vg}$ & $\mathrm{Ml}$ & 8.20 & 8.90 & 9.45 & 9.80 \\
4 & Mass flow rate of gas & $\mathrm{mf}$ & $\mathrm{Kg} / \mathrm{h}$ & 1.1956 & 1.296 & 1.3792 & 1.4292 \\
5 & Brake horse power & $\mathrm{BHP}$ & $\mathrm{Kw}$ & 0.901 & 1.159 & 1.416 & 1.674 \\
6 & Brake power & $\mathrm{BP}$ & $\mathrm{Kw}$ & 36.651 & 47.123 & 57.595 & 68.067 \\
7 & Indicated power & $\mathrm{IP}$ & $\mathrm{Kw}$ & 18.568 & 23.874 & 29.199 & 34.484 \\
8 & Specific fuel consumption & $\mathrm{SFC}$ & $\mathrm{Kg} / \mathrm{kwh}$ & 0.0326 & 0.0275 & 0.0239 & 0.0210 \\
9 & Mechanical efficiency & $\eta_{\mathrm{m}}$ & $\%$ & 1.97 & 1.97 & 1.97 & 1.97 \\
10 & Torque & $\mathrm{T}$ & $\mathrm{N}-\mathrm{m}$ & 0.5 & 0.5 & 0.5 & 0.5 \\
11 & Volume flow rate & $\mathrm{Q}$ & $\mathrm{m} / \mathrm{s}$ & $4.1 \times 10^{-7}$ & $4.45 \times 10^{-7}$ & $4.73 \times 10^{-7}$ & $4.9 \times 10^{-7}$ \\
\hline
\end{tabular}

Table 3. The results of engine parameters obtained at gear 2

\begin{tabular}{llllllll}
\hline $\mathrm{s} / \mathrm{n}$ & Parameters & symbol & unit & Trial 1 & Trial 2 & Trial 3 & Trial 4 \\
\hline 1 & Time & $\mathrm{t}$ & $\mathrm{Sec}$ & 20 & 20 & 20 & 20 \\
2 & Speed & $\mathrm{N}$ & $\mathrm{rpm}$ & 700 & 900 & 1100 & 1300 \\
3 & Volume of gas consumed & $\mathrm{V}_{\mathrm{g}}$ & $\mathrm{Ml}$ & 11.90 & 12.15 & 12.60 & 13.00 \\
4 & Mass flow rate of gas & $\mathrm{mf}$ & $\mathrm{Kg} / \mathrm{h}$ & 1.735 & 1.7729 & 1.8371 & 1.8954 \\
5 & Brake horse power & $\mathrm{BHP}$ & $\mathrm{Kw}$ & 0.901 & 1.159 & 1.416 & 1.674 \\
6 & Brake power & $\mathrm{BP}$ & $\mathrm{Kw}$ & 36.651 & 47.123 & 57.595 & 68.067 \\
7 & Indicated power & $\mathrm{IP}$ & $\mathrm{Kw}$ & 18.568 & 23.874 & 29.199 & 34.484 \\
8 & Specific fuel consumption & $\mathrm{SFC}$ & $\mathrm{Kg} / \mathrm{kwh}$ & 0.0473 & 0.0376 & 0.0319 & 0.0278 \\
9 & Mechanical efficiency & $\eta_{\mathrm{m}}$ & $\%$ & 1.97 & 1.97 & 1.97 & 1.97 \\
10 & Torque & $\mathrm{T}$ & $\mathrm{N}-\mathrm{m}$ & 0.5 & 0.5 & 0.5 & 0.5 \\
11 & Volume flow rate & $\mathrm{Q}$ & $\mathrm{m} / \mathrm{s}$ & $5.95 \times 10^{-7}$ & $6.08 \times 10^{-7}$ & $6.3 \times 10^{-7}$ & $6.5 \times 10^{-7}$ \\
\hline
\end{tabular}

Table 4. The results of engine parameters obtained at gear 3

\begin{tabular}{llllllll}
\hline $\mathrm{s} / \mathrm{n}$ & Parameters & symbol & $\mathrm{unit}$ & Trial 1 & Trial 2 & Trial 3 & Trial 4 \\
\hline 1 & Time & $\mathrm{t}$ & $\mathrm{Sec}$ & 20 & 20 & 20 & 20 \\
2 & Speed & $\mathrm{N}$ & $\mathrm{rpm}$ & 700 & 900 & 1100 & 1300 \\
3 & Volume of gas consumed & $\mathrm{vg}_{\mathrm{g}}$ & $\mathrm{Ml}$ & 14.00 & 15.10 & 16.25 & 16.90 \\
4 & Mass flow rate of gas & $\mathrm{mf}$ & $\mathrm{Kg} / \mathrm{h}$ & 2.0412 & 2.2016 & 2.3693 & 2.464 \\
5 & Brake horse power & $\mathrm{BHP}$ & $\mathrm{Kw}$ & 0.901 & 1.159 & 1.416 & 1.674 \\
6 & Brake power & $\mathrm{BP}$ & $\mathrm{Kw}$ & 36.651 & 47.123 & 57.595 & 68.067 \\
7 & Indicated power & $\mathrm{IP}$ & $\mathrm{Kw}$ & 18.568 & 23.874 & 29.199 & 34.484 \\
8 & Specific fuel consumption & $\mathrm{SFC}$ & $\mathrm{Kg} / \mathrm{kwh}$ & 0.0557 & 0.0467 & 0.0411 & 0.0362 \\
9 & Mechanical efficiency & $\eta_{\mathrm{m}}$ & $\%$ & 1.97 & 1.97 & 1.97 & 1.97 \\
10 & Torque & $\mathrm{T}$ & $\mathrm{N}-\mathrm{m}$ & 0.5 & 0.5 & 0.5 & 0.5 \\
11 & Volume flow rate & $\mathrm{Q}$ & $\mathrm{m} / \mathrm{s}$ & $7 \times 10^{-7}$ & $7.55 \times 10^{-7}$ & $8.125 \times 10^{-7}$ & $8.45 \times 10^{-7}$ \\
\hline
\end{tabular}

Table 5. The results of engine parameters obtained at gear 4

\begin{tabular}{llllllll}
\hline $\mathrm{s} / \mathrm{n}$ & Parameters & symbol & unit & Trial 1 & Trial 2 & Trial 3 & Trial 4 \\
\hline 1 & Time & $\mathrm{t}$ & $\mathrm{Sec}$ & 20 & 20 & 20 & 20 \\
2 & Speed & $\mathrm{N}$ & $\mathrm{rpm}$ & 700 & 900 & 1100 & 1300 \\
3 & Volume of gas consumed & $\mathrm{v}_{\mathrm{g}}$ & $\mathrm{Ml}$ & 17.00 & 19.00 & 20.10 & 21.00 \\
4 & Gas mass flow rate & $\mathrm{mf}$ & $\mathrm{Kg} / \mathrm{h}$ & 2.4786 & 2.7702 & 2.9306 & 3.0618 \\
5 & Brake horse power & $\mathrm{BHP}$ & $\mathrm{Kw}$ & 0.901 & 1.159 & 1.416 & 1.674 \\
6 & Brake power & $\mathrm{BP}$ & $\mathrm{Kw}$ & 36.651 & 47.123 & 57.595 & 68.067 \\
7 & Indicated power & $\mathrm{IP}$ & $\mathrm{Kw}$ & 18.568 & 23.874 & 29.199 & 34.484 \\
8 & Specific fuel consumption & $\mathrm{SFC}$ & $\mathrm{Kg} / \mathrm{kwh}$ & 0.0676 & 0.0588 & 0.0509 & 0.0450 \\
9 & Mechanical efficiency & $\eta_{\mathrm{m}}$ & $\%$ & 1.97 & 1.97 & 1.97 & 1.97 \\
10 & Torque & $\mathrm{T}$ & $\mathrm{N}-\mathrm{m}$ & 0.5 & 0.5 & 0.5 & 0.5 \\
11 & Volume flow rate & $\mathrm{Q}$ & $\mathrm{m} / \mathrm{s}$ & $8.5 \times 10^{-7}$ & $9.5 \times 10^{-7}$ & $10.05 \times 10^{-7}$ & $10.5 \times 10^{-7}$ \\
\hline
\end{tabular}




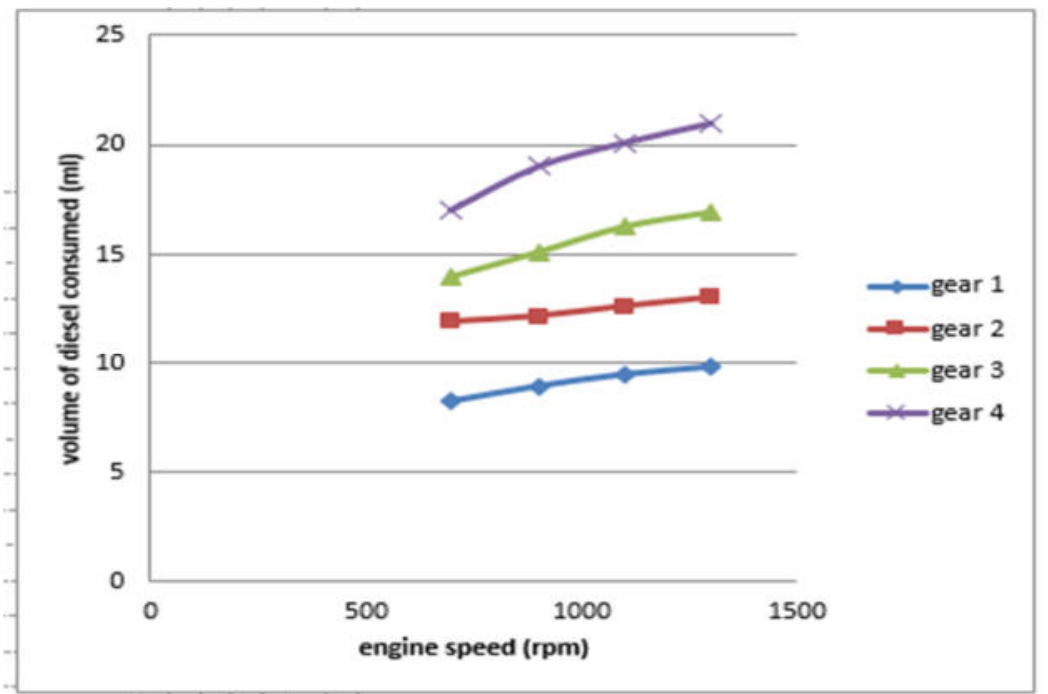

Fig.2. volume of diesel consumed versus engine speed

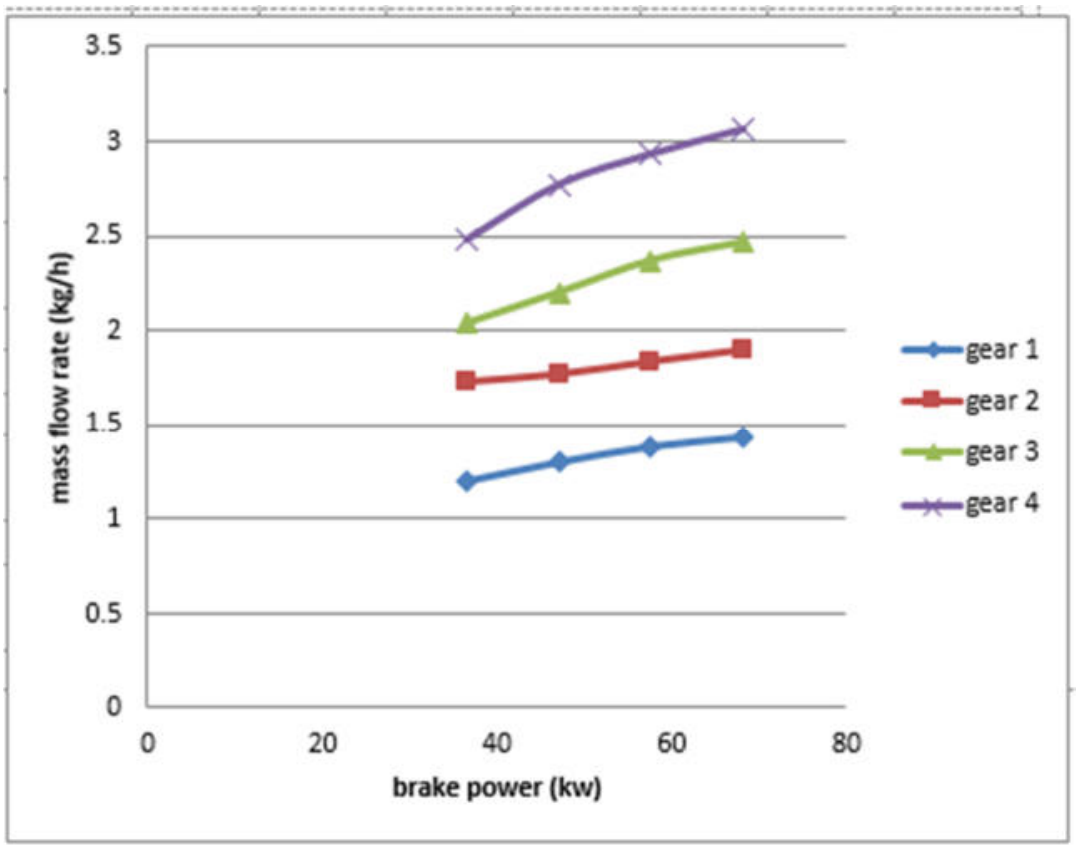

Fig 3. Mass flow rate versus brake power 

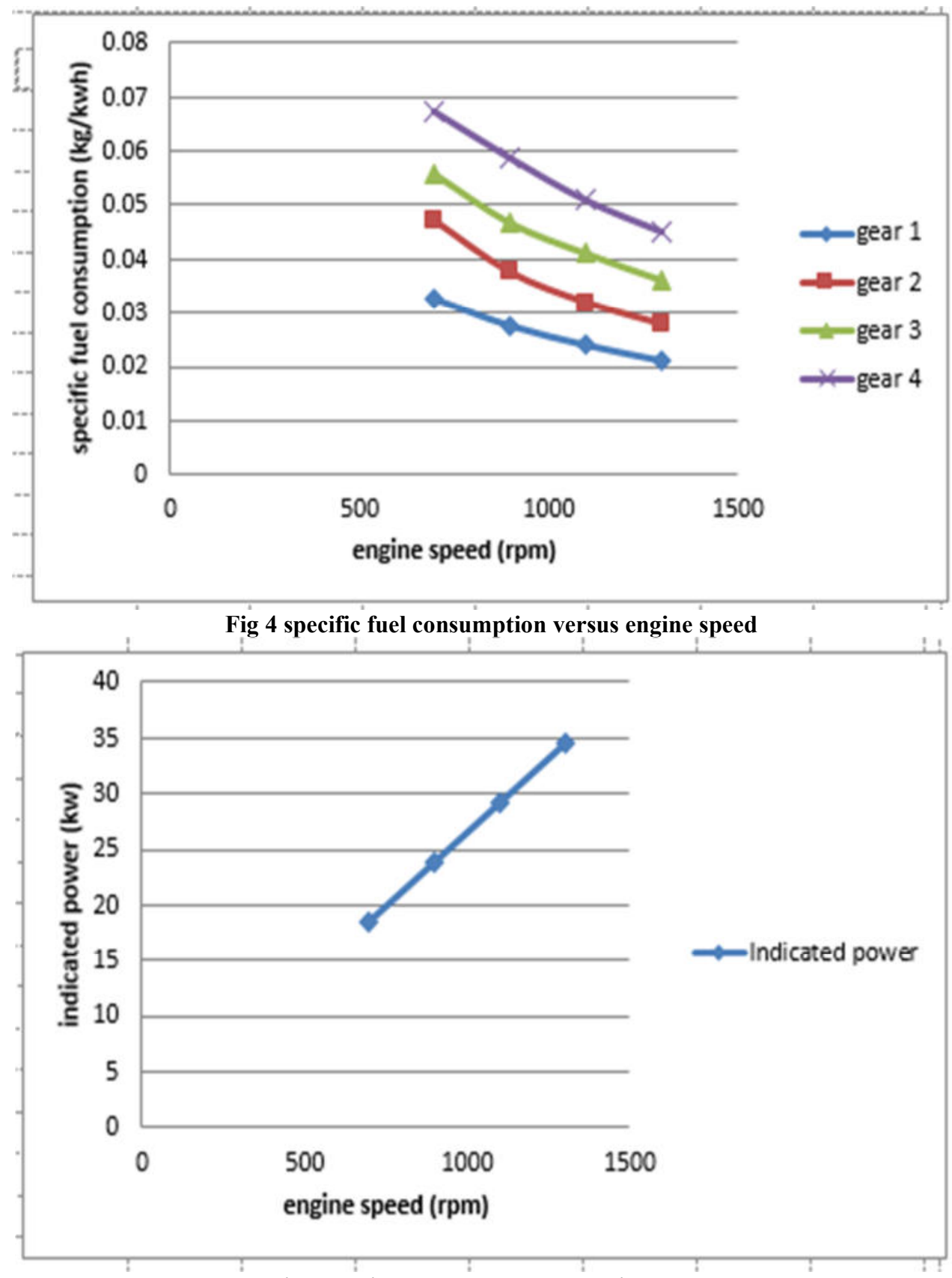

Fig 5. Indicated power versus engine speed 


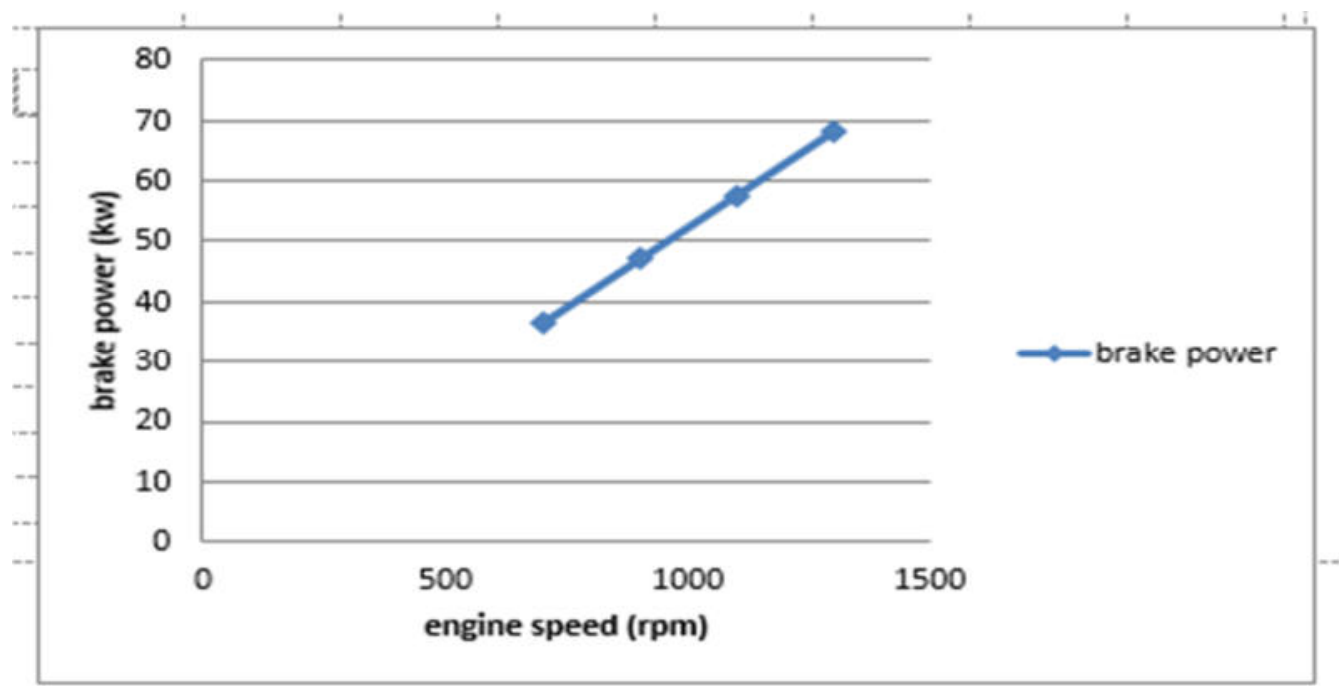

Fig 6. Brake power versus engine speed

\section{0: Conclusions:}

Volume of gas consumed increases with increasing engine speed, increases with increasing gear. Volume flow rate increases with increasing brake power, increases with increasing gear. Fuel mass flow rate increases with increasing brake power, increases with increasing gear. Specific fuel consumption decreases with increasing brake power.. Specific fuel consumption decreases with increasing engine speed. Indicated power increases as engine speed increases

\section{References}

Allan Bonnick, Dere Newborn, (2011): A Practical Approach To Motor Vehicle Engineering and Maintenance, $3^{\text {rd }}$ edition, Elsevier ltd the boulevard Langford lane, Oxford.

Baumgarter, B. and Carsten, T (2006): Mixture Formation in Internal Combustion Engines, Springer, Berlin. Dolan, J.A (1976): Motor Vehicle Technology and Practical, Work Art 1 and 2, London.

Eastop, T.D and McConkey, A (2006): Applied Thermodynamics for Engineering Technologist, $5^{\text {th }}$ edition, Dorling Kinders ew Delhi. PP 345.

Ganeshan, V (2008): Internal Combustion Engine, $3^{\text {rd }}$ edition, McGraw Hill New York.

Heywood, J.B (1998): Internal combustion Engine Fundamentals, McGraw Hill, Singapore.

Hillier, V.A.W and Patrck, F (1988): Fundamentals of Motor Vehicle Technology, $3^{\text {rd }}$ Edition, Hutchinson Publishers. Khurmi, R. K. and Gupta, J.K (2000): A Textbook of Thermal Engineering, Chands and Co.Ltd., Ram Nagar, New Delhi.

Nag, P.K (2001): Power Plant Engineering, $2^{\text {nd }}$ Edition, Tata McGraw Hill Publishing, New Delhi. Onkar, Singh, (2008): Applied Thermodynamics, $3^{\text {rd }}$ edition, New Age International Publishers India. Rai, G.D (2006): An Introduction to Power Plant Technology, $3^{\text {rd }}$ edition, Khana Publishers New Delhi. 